10.53116/pgaflr.2018.2.10

\title{
Complaint in Tax Administration as an Instrument to Ensure Good Administration ${ }^{1}$
}

\author{
Zuzana Marethová*
}

\begin{abstract}
* Zuzana Marethová, postgraduate student, Department of Financial Law, Faculty of Law, Masaryk University, the Czech Republic. The author specialises in tax procedural law. (e-mail: 344107@ mail.muni.cz)
\end{abstract}

\begin{abstract}
This contribution deals with the legal institute of complaint as an instrument to ensure good administration, more precisely good tax administration. The main aim of the contribution is to confirm or disprove the hypothesis that a complaint is an institute that effectively protects people involved in tax administration and thereby mediates good governance. In the contribution, the method of analysis will be used to analyse and define theory and legal regulation.
\end{abstract}

Keywords: good governance; good administration; good tax administration; law; Tax Law; Tax Code; complaint

\section{Introduction}

The aim of this contribution is to discuss the legal institute of complaint as an instrument to ensure good tax administration. Good administration (governance) as one of the basic pillars of the modern rule of law must be obviously protected. This protection is ensured through a variety of institutes. For example, we can refer to the means of protecting the rights of tax subjects which, in addition to this protection, also ensure respect for the principles of good administration. One of these means is a complaint which has a special place among the other means of protecting the rights of taxpayers. It should serve as a fast, operational and effective institute.

The hypothesis of this contribution is that the complaint is an effective institution protecting good governance (and the rights of taxpayers). Throughout the paper, an analytical method will be used to build the text of this contribution.

Nowadays, the issue of complaint is elaborated particularly in decisions of regional courts and judgments of the Supreme Administrative Court. In the academic environment, the topic (complaint) was in general a subject of research especially of Jeroušek, ${ }^{2}$ Burda $^{3}$ and partly myself. ${ }^{4}$ However, these works do not take complaint as complexly as this paper.

The article will be split into chapters in which good administration will generally be discussed first and then complaint will be addressed as an institute targeting to protect this good administration. 


\section{Good Administration}

Good administration, respectively good administrative practice is difficult to grasp and define. On a theoretical level, good administration is defined for example by Potešil according to who the term "good governance" includes a set of requirements that aim to ensure the quality and proper functioning of public administration in the conditions and environment of a modern democratic rule of law based on respect for fundamental rights and the freedoms of individuals. In other words, good administration is about such a performance of public administration that can be denoted by an adjective expressing its positive attribute - good. ${ }^{5}$

The introduction of the concept of good administration into the legal systems of many states is a merit of the Council of Europe, in particular of its Recommendation CM/ $\operatorname{Rec}(2007) 7$ of the Committee of Ministers to member states on good administration. This document recommends that the governments of member states promote good administration within the framework of the principles of the rule of law and democracy; promote good administration through the organisation and functioning of public authorities ensuring efficiency, effectiveness and value for money. These principles require that member states ensure that objectives are set and performance indicators are devised in order to monitor and measure, on a regular basis, the achievement of these objectives by the administration and its public officials; compel public authorities to regularly check, within the remit of the law, whether their services are provided at an appropriate cost and whether they shall be replaced or withdrawn; compel the administration to seek the best means to obtain the best results; conduct appropriate internal and external monitoring of the administration and the action of its public officials; promote the right to good administration in the interest of all, by adopting, as appropriate, the standards set out in the model code appended to this recommendation, assuring their effective implementation by the officials of member states and doing whatever may be permissible within the constitutional and legal structure of the state to ensure that regional and local governments adopt the same standards. ${ }^{6}$

To the described Recommendation, the Code of good administration is attached which contains twenty-two basic principles divided into three sections. The most important of these include: principle of equality, principle of impartiality, principle of proportionality, principle of legal certainty, principle of taking action within a reasonable time limit, principle of participation, principle of respect for privacy and principle of transparency. ${ }^{7}$

In the European Union, good governance is based on Article 41 of the Charter of Fundamental Rights of the European Union, entitled the Right to Good Administration, under which everyone has the right to have his or her affairs handled impartially, fairly and within a reasonable time by the institutions, bodies, offices and other bodies of the Union. This right includes, in particular, the right of everyone to be heard before the adoption of an individual act which could affect him; the right of everyone to have access to the file relating to him, while respecting the legitimate interests of confidentiality and professional and business secrecy, and the obligation of the administrative authorities to justify their decisions. According to that article, everybody is also entitled to the compensation of 
damage caused by the institutions of the Union or by its employees in the performance of their duties and the right to write to the institutions of the Union in one of the Treaty languages and receive a reply in the same language.

In response to this article of the Charter of Fundamental Rights of the European Union, the European Parliament has adopted the European Code of Good Administrative Behaviour applicable to the institutions and officials of the European Union. The Code emphasises, for example, the principles of legality, non-discrimination, proportionality, prohibition of misuse of powers, impartiality and independence, objectivity, legitimate expectations, consistency, justice, courtesy or replies in the language of the citizen. ${ }^{8}$

\subsection{Czech tax law and good administration}

The Czech national law, like the EU law, operates with the institute of Good Administration, but it does not define it. ${ }^{9}$

The basic procedural law regulating administrative proceedings, the Administrative Code ${ }^{10}$ in its Article 8(2), rules that the administrative authorities cooperate with each other for the sake of good administration; the legal principle is however not further explained or developed.

The main tax procedural regulation (which a priori concerns this contribution), the Tax Code, ${ }^{11}$ does not explicitly include the term of good administration. It contains, however (similarly to the Administrative Code and to the above-mentioned EU documents and documents of the Council of Europe) a catalogue of the basic principles of tax administration, whose incorporation in the law sought to achieve, among other things, good tax administration. These are the principles of legality, legal license, restraint and proportionality, procedural equality, co-operation, instructional helpfulness and courtesy, speed and economy of management, free assessment of evidence, legitimate expectation, material truth or non-publicity.

Thus, the basic principles of tax administration, as a whole, ensure good governance in the area of tax law. Their effectiveness is ensured by being directly binding. They are important interpretative rules that need to be taken into account when interpreting individual tax provisions. The principles express certain rules that apply at any stage of tax administration. These basic principles of tax administration govern not only the behaviour of the tax administrator and the tax subjects, but also all other persons involved in tax proceedings. The principles are legally binding unless other special provisions contain exceptions. ${ }^{12}$

\subsection{Means to meet the requirement of good governance}

As has already been mentioned, the basic principles of tax administration and the good administration provided by them are intertwined through the entire legal regulation of the tax process. The tax administrators are therefore obliged to respect them in all their procedures. But it would be illusory to think that all tax administrators do so in all their actions. It is therefore necessary for the procedural regulation to contain the means 
to check compliance with the principles of good tax administration, respectively of all duties of the tax administrator. It is precisely these means that ensure that the tax administrators will act in accordance with the principles of good administration in the exercise of their powers.

The Czech legal framework of tax procedural law contains a wide range of these means aimed at remedying the undesirable situation in tax administration. For example, proper and exceptional remedies can be named.

Among these remedies, which ensure full respect for the principles of good administration, the legal institute of the complaint set out in Article 261 of the Tax Code takes up to a certain extent the specific status. This institute will be the subject of the following text of this contribution.

\section{Complaint under Article 261 of the Tax Code - General Principles}

Immediately at the beginning, it is necessary to briefly define what the Tax Code understands by a complaint. With a complaint any person involved in tax administration may defend against inappropriate behaviour of tax officials or against the procedure of the tax administrator if the tax law does not provide any other means of protection. It is therefore a universal subsidiary means of protecting the rights of taxpayers as illustrated below in more details. It is clear from this brief definition that the complaint is quite a versatile institute which can be used in many cases of breach of principles of good tax administration.

A brief historical excursion has to be mentioned at the very beginning. Since no legislation can be perceived in isolation, it is necessary to look in the past and identify the origin of the institute under examination. The institute of complaint itself is fairly new in its pure form in tax law. Its tax governance enactment did not take place until January 1 , 2011, that is, from the effective date of the new procedural regulation, the Tax Code. The previous legal regulation of the tax process, i.e. the Act on the Administration of Taxes and Fees, ${ }^{13}$ explicitly did not include this institute. The explanatory report relating to the complaint states that the complaint institute is newly included as a general means of protecting taxable persons when they encounter inappropriate tax treatment or inappropriate behaviour of tax administrators.

Complaint is therefore a new legal institute within the Czech Tax Law, but not within the entire Czech legal order. The complaint has been taken over in the area of tax administration in accordance with the model applied in the "general" administrative procedure. For more than 10 years, the administrative procedure includes the legal institute of complaint. It was this law that became a model for a "tax" complaint, which caused the legal texts of both legal institutes to be practically identical. However, it is quite clear that, while administrative and tax law are very close, they are not the same legal sector with the same basic foundations, so the simple "copying" of legal regulation from one legal sector to another does not seem ideal. 
After a brief description of the historical circumstances, it is necessary to elucidate the basic points of the complaint, since without these the following text would be hardly comprehensible.

As stated above, the complaint can be targeted at inappropriate behaviour of the tax authorities' official or at procedures of the tax administrator. The tax administrator responsible for processing the complaint is under an obligation to assess the claims made in the complaint and subsequently inform the complainant of the outcome of the assessment. If the complainant is not satisfied with the way his complaint was assessed, he/she is entitled to file a so-called request to investigate how the complaint was assessed to the superior tax administrator. The superior tax administrator is required, based on this submission, to investigate whether the complaint has been duly processed. Both the first-rate tax administrator and the superior tax administrator could then take measures to remedy the undesirable situation.

The complaint is to some extent an atypical legal institute. It is enshrined only in a single legal provision and this relatively brief regulation to some degree pre-empts its nature. The complaint, more precisely the procedure for its processing, is not bound by extensive procedural rules, which makes the complaint a less formalised means of protection of rights. It is therefore a relatively quick and effective means of remedying the possible misconduct of the tax administrator, in which the emphasis should be on the outcome, i.e. the correction of any maladministration. The words of the Supreme Administrative Court of the Czech Republic are as follows: "Complaint processing and investigating the way complaints are handled are less formal procedures, whereby the emphasis should be on the outcome of these procedures (removal of illegality), not on the actual procedural aspect of their implementation." 14

In the same informal spirit, the process of dealing with complaints is also carried out. The systematic classification of a complaint under the Tax Code in Part Five entitled Common Provisions, Authorizing, Transitional and Final leads to the conclusion that a complaint is not handled in the context of "classical proceeding". Similarly, the outcome of the complaint investigation (financial authorities call it "notification") is not a decision. This fact is quite significant. It means, for example, that it is not possible to appeal against it. In addition, rules relating to the content of the decision are not applicable to the notifications. This, of course, does not mean that the tax administrator could handle the complaint with an informal note in which there would be no details about the processing of the complaint. The notification, although not a decision, must contain an adequately detailed and verifiable justification. The financial administration respects the above, while constantly informing the complainant about his/her complaint with notifications in which the tax administrator deals with the individual objections contained in the complaint.

\subsection{Admissibility of the complaint}

Although the law does not explicitly stipulate that the tax administrator may consider the complaint inadmissible, the tax administrator is constantly doing so within his already established administrative practice. If all the conditions for the admissibility of a complaint 
are not met, the tax administrator will consider the complaint inadmissible; as a result of this fact claims stated in the complaint will not be substantively examined. Consequently, the conclusion that the complaint is inadmissible may have a major impact on the complainant. It is therefore necessary to consider thoroughly whether a complaint is admissible or not.

Except in practice virtually non-occurring situations, such as violations of the ne bis in idem principle or the submitting of a complaint by a person who is not at all concerned with the contested procedures, the most important condition of admissibility of complaint is compliance with the condition of so called subsidiarity of the complaint. The legislation clearly states that a complaint may be successfully filed only if the tax law does not provide any other means of protection. It is clear, therefore, that the complaint is a subsidiary means, a means of ultima ratio, as already mentioned above. If there is another means of protection, it is not possible to file a complaint in the same case.

The above conclusion was explicitly stated by the Supreme Administrative Court: "The complaint and the request to investigate the handling of a complaint are, by their nature, subsidiary, residual remedies which serve to protect the rights of the parties, unless the law foresees the application of other remedies." ${ }^{15}$ In this context, it must be emphasised that the very existence of another means of protection will lead to the inadmissibility of the complaint, it is not necessary for it to be actually used. Similarly, it is not possible to successfully file a complaint against how this other means of protection has been dealt with.

However, it remains a relatively problematic issue which institutions can be included in a group of other means of protection that exclude complaints. The law does not define these at any rate. Generally, in my opinion, these can be defined as any statutory means of protection which are capable of providing protection of the rights of a person involved in the administration of taxes and which that person may initiate. In some cases, there is no dispute that there are other means of protection. For example, if the taxpayer is convinced that the tax administrator is inactive in his case, he should file a complaint to protect the inaction of the tax administrator, not a complaint. In other situations, however, the situation is not so obvious. Some guidance provides the practice of the tax administrator and the related case law of the administrative courts. In its judgment of 3 November 2015, No. 2 Afs 143/2015 - 71, the Supreme Administrative Court stated that: "The Tax Code regulates the large amount of means of protection that will prevail before the filing of the complaint; such as appeal, remonstrance, objection in the phase of paying the taxes, renewal of proceedings, review proceedings, protection against inactivity, request for an extension of term, complaints about the procedure of the tax payer, objection to bias, etc."Based on this judgment, it can be concluded that the set of protection meaning of Section 261(1) of the Tax Code is very wide.

\subsection{Actions of the tax administrator that can be challenged by a complaint}

As noted above, a complaint is a means for individuals involved in tax administration to prevent "improper conduct by tax officials" or "tax administrator procedure". These are two relatively closed groups of phenomena against which (if other conditions are met) one can successfully be defended by complaint. 


\subsection{Complaint against inappropriate behaviour of tax officials}

The first set of actions to which the legal provisions of the complaint refer is the inappropriate conduct of tax officials. If, therefore, there is a situation during the tax administration in which a person involved in tax administration gives the impression that an official is acting in an inappropriate manner, he or she may oppose such conduct by a complaint. It is quite obvious that the inappropriate behaviour of tax officials is highly undesirable, precisely because it violates the basic principles of good administration, which also include the duty of officials to act professionally and courteously towards the addressees of legal norms.

However, it can be said that complaints aiming to the inappropriate conduct are not so frequent in practice. There are several reasons for this, in my opinion. Firstly, this type of complaint is relatively problematic as regards the proof of misconduct, i.e. the inappropriate conduct of an official. For obvious reasons, these cases will almost always be based on the "claim against claim" situation. Furthermore, there is a problem with regard to possible remedial measures in case of this complaint. The inappropriate behaviour of tax officials will, in the vast majority of cases, take the form of a one-off time-bound act; it will not be a long-term and ongoing process. For this reason, only remedial measures in the form of a finding of inappropriate conduct will be considered and, if necessary, prohibiting further inappropriate behaviour in the future (if the inappropriate behaviour of the official would reach a certain intensity, it is not excluded that the competent authorities would start disciplinary proceedings with the guilty party, but any disciplinary sanction would not be a priori remedy for the complaint). Lastly, it is to be hoped that one of the reasons for the small number of complaints against the inappropriate behaviour of tax officials is the fact that such inappropriate behaviour occurs only exceptionally.

\subsection{Complaint against the procedure of the tax administrator}

The subject of the complaint may also be the "procedure" of the tax administrator. Given that the law does not define what is meant by such a procedure, this type of complaint is quite problematic. However, from the systemic and regulatory contexts, it follows that the procedure is a generic term involving both formal proceedings and other procedures. Given that it is such a large set, it is necessary to look for guides in the relevant court practice. It follows that a tax audit can be challenged by a complaint (judgment of 13 February 2014, No. 2 Aps 8/2013 - 46). Conversely, one cannot file a complaint to challenge the tax administrator's progress in assessing evidence (judgment of 3 November 2015, No. 2 Afs $143 / 2015-71$ ). In addition, it is implicit in the above-mentioned judgment that a decision cannot be challenged by a complaint, since the court stated that another remedy preventing the filing of a complaint must also be regarded as an appeal and the initiation of a review proceeding. ${ }^{16}$ Apart from the above mentioned cases, however, there is no general definition of procedures that may be challenged by a complaint. It may be added that such a definition is practically impossible to make and that such an attempt at generalisation could prove to be counterproductive. There are many different procedures in tax administration, and even the best tax law expert is certainly not able to identify and generalise all of these. 


\subsection{Investigation of the complaint}

The actual process of dealing with the complaint, i.e. its assessing, is not in detail defined in the law. The legal regulation only defines that the tax administrator will assess the facts set out in the complaint. First of all, it follows that the dispositional principle applies in the processing of a complaint, as the tax administrator is required by law to examine only the facts set out in the complaint (of course, this does not change the fact that the tax administrator should correct the unlawful procedures not given in the complaint, if he finds any during the assessing). Furthermore, it follows from the above standard that after the filing of the complaint, the tax administrator is obliged to deal with the claims contained therein. This procedure will not be bound by any rigid procedural rules. It is therefore up to the tax administrator to choose the procedure for the purpose of the assessing the complaint. In this respect, the law prescribes that the tax administrator is (in order to clarify the facts objected to in the complaint) entitled to hear the complainant and other persons whose explanation could help to clarify the matter. In administrative practice, however, the tax administrator does not practice such interrogations. However, it can be inferred from the general principles that if the complainant asks to carry out the interrogation of the persons identified by him (or any other evidence), the tax administrator would have to either do it so or adequately justify why it is not necessary to do so.

In order to fulfil the effectiveness and the operability of the complaint, the law requires the tax administrator should settle the complaint within 60 days. The deadline can be exceeded only if it is not possible to provide the necessary documents for processing the complaint. Regarding the time limit, it is noted that the legislation has recently included a rule according to which the tax administrator is obliged to settle the complaint against the inappropriate conduct of the official in the tax audit or the procedure of the tax administrator at the tax audit no later than the end of the tax audit. This standard was omitted from the Tax Code by an amendment made by Act No. 170/2017 Coll. The explanatory statement highlights the frequent occurrence of obstructive complaints filed not for the purpose of remedying the defective condition but for the purpose of continuously extending the tax audit. ${ }^{17}$

If the tax administrator considers the complaint reasonable, the administrator should take corrective action. The law does not specify these measures.

\subsection{Request to investigate how the complaint was handled}

As already mentioned above, the legal framework of the complaint also contains a quasiremedy against the assessing (investigating) of the complaint. If the complainant is not satisfied with how the tax administrator has dealt with his complaint, the superior tax administrator may be asked to investigate the way the complaint was handled. The superior tax administrator then evaluates whether the complaint has been properly processed. If this administrator concludes that this was not the case (either because the tax administrator incorrectly judged the complaint as unreasonable or did not take adequate remedies), the complaint will not be returned to the first-level tax administrator (the superior tax 
administrator will not proceed on a "cassation" principle) on the contrary, the superior tax administrator will take measures to redeem himself. This approach reflects the nature of the complaint as an institute aimed at an effective and rapid remedy which is not bound by rigid procedural rules.

It should also be noted that, in the past, the financial authorities had a kind of inappropriate way to deal with the described requests to investigate how the complaint was handled. Instead of actually assessing the objections contained in the request, the tax administrator was only focused on how the complaint was handled procedurally. However, this approach has already been abandoned and, in the course of investigating how the complaint is handled, the supreme tax administrators deal not only with the tax subordinate administrator's procedure (adherence to deadlines, the settlement of all claims, etc.) but also with the substantive aspect of the matter (whether the tax administrator considered correctly the complaint reasonable or unreasonable).

\section{Conclusion}

Good governance is one of the cornerstones of every state governed by the rule of law. It is essential for public administration to be based on principles which, in its entirety, ensure its legitimate, efficient, economic and equitable functioning. Such functioning ("good functioning") will, of course, be subject to scrutiny, both internal (control carried out within the public administration) and external (carried out, for example, by the addressees of the public administration). Such external control takes place in particular on the basis of the individual means of protection initiated by the addressees of public rights and obligations.

A specific position among these means, within the framework of tax law, takes a complaint which is a subsidiary means of protecting the persons involved in the administration of taxes against the procedures of the tax administrator and against the inappropriate conduct of the tax authorities.

From the above mentioned theoretical and legal grounds, in my opinion, it is clear that the complaint is an effective institute of protecting the principles of good administration. It is a very generic means of making it possible for all concerned to draw attention to the mistakes of the tax administrator. The complaint also works on informal grounds, and its main goal is to quickly and operationally remedy the malfunction. The fact that the legal arrangement has a two-stage approach to its handling is added to its effectiveness. If the complainant is not satisfied with how his complaint has been dealt with, he has the right to file a request to the superior tax administrator to investigate the way the complaint was handled. Nor can it be overlooked that the remedy that the tax administrator is obliged to accept on the basis of the complaint is not defined in any detail in the law, which leads to the clear conclusion that the tax administrator is entitled to do anything (legal), which will lead to the correction of the defective state. For these reasons, it is necessary to conclude on confirming the hypothesis of this contribution because the complaint is certainly an effective means of protecting good administration. 


\section{References}

1 This article is the outcome of the research projects: MUNI/A/1017/2017 (Selected aspects of direct taxes and their interpretation and application in the jurisprudence II).

2 David Jeroušek, Stížnost dle daňového řádu v průběhu daňové kontroly [Complaint according to the Tax Code during tax audit], 2, in Daňový expert, [Tax Expert] no. 4 (2013).

3 Zdeněk Burda, Stížnost v judikatư̌e správních soudů [Complaint in the case law of the administrative courts], 70, in Dané a právo v praxi, [Taxes and Law in Practice] no. 7 (2014).

4 Zuzana Marethová, Podmínky př́pustnosti stížnosti podle $\$ 261$ daňového řádu [Conditions of admissibility of a complaint under Section 261 of the Tax Code], DAUC.cz - dané, [DAUC.cz - Taxes] no. 7 (2017), in ASPI, Legal system (accessed 3 May 2018).

5 Lukáš Potěšil, „Dobrá správa” v dokumentech Rady Evropy [Good administration in the European Council documents], Veřejná správa, [Public Administration] no. 12 (2008), www.mvcr.cz/docDetail. aspx ?docid $=21308870 \&$ doctype $=$ ART $($ accessed 3 May 2018).

6 Recommendation $\mathrm{CM} / \operatorname{Rec}(2007) 7$ of the Committee of Ministers to member states on good administration, https://rm.coe.int/16807096b9 (accessed 6 May 2018).

7 Appendix to Recommendation CM/Rec(2007)7 of the Committee of Ministers to member states on good administration, https://rm.coe.int/16807096b9 (accessed 6 June 2018).

8 European Code of Good Administrative Behaviour, www.ombudsman.europa.eu/en/resources/code. faces\#/page/ 1 (accessed 6 May 2018).

9 It is worth mentioning that the Czech Ombudsman has defined ten principles of good governance in his practice: compliance with law, impartiality, timeliness, predictability, persuasiveness, proportionality, efficiency, responsibility, openness and helpfulness.

10 Act No. 500/2004 Coll., the Administrative Code, as amended.

11 Act No. 280/2009 Coll., the Tax Code, as amended.

12 Lenka Matyášová, Marie Emilie Grossová, Daňový rád. Komentár [Tax Code. Commentary], $2^{\text {nd }}$ edition, 40, (Praha, Nakladatelství Leges, 2015).

13 Act No. 337/1992 Coll., Act on the Administration of Taxes and Fees, as amended.

14 Supreme Administrative Court: 9 Aps 4/2013.

15 Supreme Administrative Court: 4 Afs 213/2016.

16 Marethová, supra n. 4.

17 www.psp.cz/sqw/text/tiskt.sqw ?O=7\&CT=873\&CT1 $=0$ (accessed 6 May 2018). 